\title{
Operating information-diagnostical system (IDS) BING-3 on the example of Andijan water reservoir
}

\author{
Norkobul Rahmatov", Jamshid Choriev, and Oshiqmamut Ibraymov \\ Tashkent Institute of Irrigation and Agricultural Mechanization Engineers, Tashkent, Uzbekistan
}

\begin{abstract}
The article provides recommendations on the possibility of implementing an automated system of diagnostical control over the operational condition of a dam. Implementation of BING-3 allows to control the opening of cracks in concrete structures, take readings from piezometers and air temperature sensors in an automatic regime. The article gives an analysis of instruments used for diagnostics and reasons for the failure of certain devices. It has been established that further use of morally out-of-date devices reduces dam safety observation volumes.
\end{abstract}

\section{Introduction}

The majority of earth-fill and concrete dams in the republic were built in the middle of the last century. Correct technical solutions, implemented in the design of these dams, allowed to operate them for over fifty years $[1,2]$. However, nowadays, the control over the dams is carried out by manual measurements of two or three coordinate crack measurers, pressure and non-pressure piezometers, reverse plumbs [19, 20]. Also, earth-fill and concrete structures of hydrosystems have many marks installed, whose positions are controlled relative to reference points using geodetical equipment. Such a system of controlmeasurement instrument management does not meet current requirements [1]. Time requires reequipping of all average and high pressure dams with modern instruments. When implementing automated systems of diagnostical control, several problems of financial origin may come out, including personnel training, etc.

In this article, we consider the issues concerning technical solutions for implementing automated systems of diagnostical control at the Andijan water reservoir (Figure 1).

\footnotetext{
* Corresponding author: rnr08@yandex.com
} 

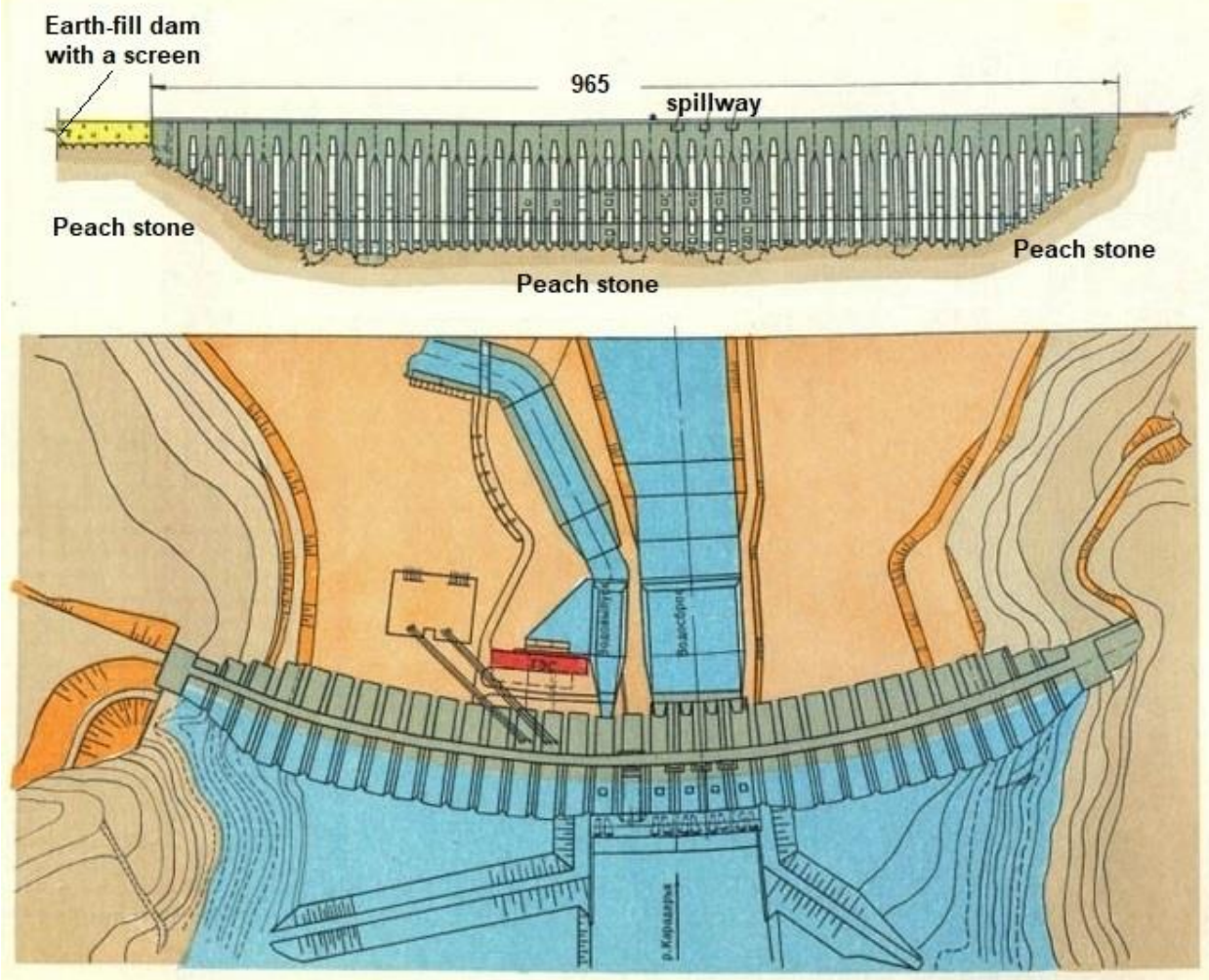

Fig. 1. Plan view and cross-section view of Andijan water reservoir

The goal of the work is to justify the practicability of implementing the system of diagnostical control over the operational condition of a concrete dam.

The task of improving the control over earth-fill and concrete dam conditions is determined with the necessity of providing the safety of operation of very important and technically complex facilities $[3,4,10,11,15]$.

The main task of monitoring is to control the operational condition of hydrosystems. Monitoring is carried out using both inset control and measurement equipment, installed in the process of construction, geodetic, seismometric, other instrumental methods, and visual observations [21-36].

\section{Methods}

The research was carried out using the traditional method of conducting field research of structures.

There is a big experience accumulated throughout the world on implementing automated systems of diagnostical control over the technical condition of dams, for example, BING-3 [7,8,9,13,14].

BING-3 system operates in the automatic regime and carries out control over the opening of cracks in concrete structures, records piezometer and air temperature sensor readings. The system has successfully recommended itself at Orto-Tokoy water reservoir in Kirgizstan, being used since 2014 [13]. 


\section{Results and Discussion}

All the control and measurement equipment listed in table 1 must be replaced in Andijan water reservoir.

Table 1. Amount of instrumentation requiring reequipment. Static control and measurement equipment.

\begin{tabular}{|c|c|}
\hline Static control-measuring instrumentation: & Amnt. \\
\hline String and semiconductor transformers & 1119 ea. \\
\hline \multicolumn{2}{|l|}{ Filtration Control Measurement Instrumentation: } \\
\hline Pressure piezometers & 108 ea \\
\hline Nonpressure piezometers & 100 ea. \\
\hline Including inside the dams & 100 \\
\hline Measuring weirs & 22 ea. \\
\hline Springs at the dam tailrace & 5 ea. \\
\hline \multicolumn{2}{|l|}{ Geodetic Control Measurement Instrumentation: } \\
\hline Fundamental reference marks & 6 ea. \\
\hline $\begin{array}{ccc}- & \text { Operation reference marks } \\
- & \text { Direct plumbs } \\
- & \text { Reverse plums } \\
\text { Range signs in galleries at levels } 817,845,885\end{array}$ & $\begin{array}{l}140 \text { ea. } \\
8 \text { ea. } \\
16 \text { ea. } \\
103 \text { ea. }\end{array}$ \\
\hline Hydrostatic elevation meter (level) (at 4 sections) & 48 ea. \\
\hline Uniaxial and triaxial crack meters & 44 ea. \\
\hline \multicolumn{2}{|l|}{ Seismic Control Measurement Instrumentation } \\
\hline Seismic detectors & 53 ea. \\
\hline \multicolumn{2}{|l|}{ Hydraulic Control Measurement Instrumentation } \\
\hline Concrete failure sensors, including: & 39 ea. \\
\hline at $1^{\text {st }}$ tier waterways & 10 ea \\
\hline at water outlet stilling basin & 15 ea \\
\hline at spillway stilling basin & 14 ea. \\
\hline Sensors of wearing of metal, including: & 20 ea. \\
\hline at section №16 waterways & 10 ea \\
\hline at section №21 waterways & 10 ea \\
\hline Pressure pulsation sensors & 34 ea \\
\hline Cavitation sensors & 18 ea \\
\hline \multicolumn{2}{|l|}{ Inserts at section №21 and cable for measurement of: } \\
\hline pressure and aerations & 4 ea \\
\hline velocity and aeration & 4 ea \\
\hline Vibration sensors, including: & 32 ea \\
\hline in the body of sections №16, №17, №21 and №22 & 18 ea \\
\hline at spillway stilling basin & 14 ea \\
\hline
\end{tabular}

For measurements of deformations and temperature at the base and in concrete, openings of deformation joints and cracks, measurement of filtration pressure, string and semiconductor transformers of static control, and measurement instrumentation were installed in the dam [1]. The frequency of alternating voltage at transformer outlet or active 
resistance of semiconductor thermoresistor serves as information parameter of the electrical signal $[11,12]$. Types of these transformers and their measuring limits are given in Table 2.

Table 2. Types of string transformers used for observations

\begin{tabular}{|c|c|c|c|c|c|}
\hline № & Transformer type & Abbreviation & $\begin{array}{c}\text { Unit of } \\
\text { measurement }\end{array}$ & $\begin{array}{c}\text { Range of } \\
\text { values }\end{array}$ & Function \\
\hline 1 & $\begin{array}{c}\text { Linear displacement } \\
\text { transformers, string } \\
\text { type }\end{array}$ & PLPS & $\mathrm{mm}$ & $0-1,0-3,0-6$ & $\begin{array}{c}\text { Measurement of } \\
\text { the amount of } \\
\text { joint and crack } \\
\text { opening }\end{array}$ \\
\hline 2 & $\begin{array}{c}\text { Linear deformation } \\
\text { transformers }\end{array}$ & PLPS & $\mathrm{mm}$ & $0.1 ; 0.22 ; 1$ & $\begin{array}{c}\text { Measurement of } \\
\text { relative linear } \\
\text { deformations }\end{array}$ \\
\hline 3 & $\begin{array}{c}\text { Force transformers, } \\
\text { string type }\end{array}$ & AD & $\mathrm{kN}$ & 80 & $\begin{array}{c}\text { Measurement of } \\
\text { tensile and } \\
\text { compressive } \\
\text { forces in rebar }\end{array}$ \\
\hline 4 & $\begin{array}{c}\text { Pressure } \\
\text { transformers, string } \\
\text { type }\end{array}$ & PD & MPa & 3,10 & $\begin{array}{c}\text { Measurement of } \\
\text { hydrostatic } \\
\text { pressure in } \\
\text { concrete and } \\
\text { joints }\end{array}$ \\
\hline 5 & $\begin{array}{c}\text { Transformers for } \\
\text { temperature } \\
\text { temperature } \\
\text { transformers }\end{array}$ & PTS-60 & degrees & from -20 to \\
+60 & $\begin{array}{c}\text { Temperature } \\
\text { measurement }\end{array}$ \\
\hline
\end{tabular}

Section 18

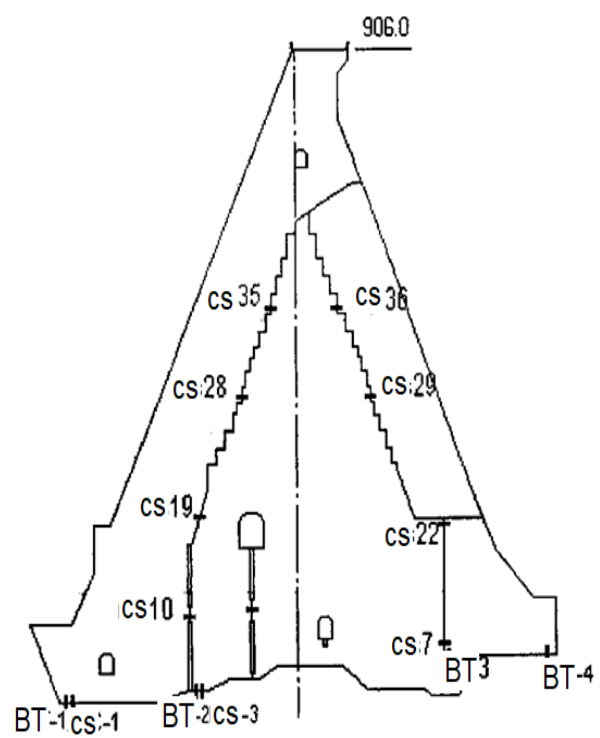

Section 24

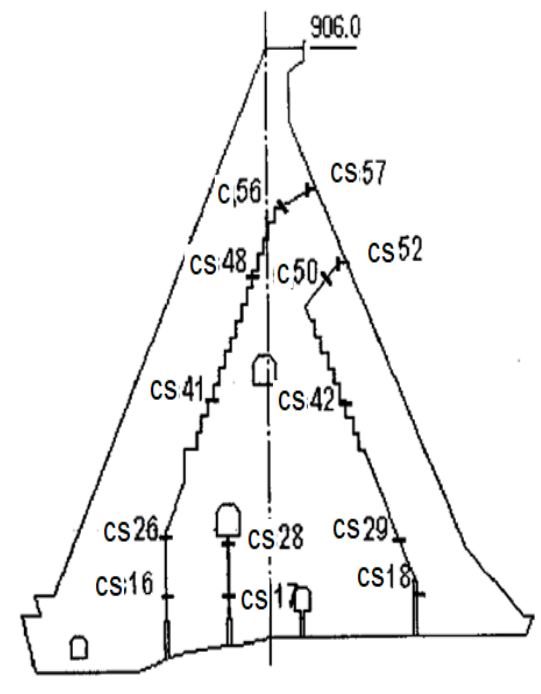

Fig. 2. Location of crack meters at the axis of right buttress section 18, 24. 
In 2015 observations by static control measurement instrumentation were carried out every 10 days. Monthly checks of the number of sensors, which transmitted data, showed that their amount has decreased compared to 2014.

Table 3 shows data on the number of transformers used to take measurements in 20142015 and the decrease of the number of transformers used for observation in December of 2015 compared to June of 2014.

Table 3. The number of transformers used for observations.

\begin{tabular}{|c|c|c|c|c|c|c|}
\hline Transformer description & 2010г. & $\begin{array}{c}2014 \\
20-V I\end{array}$ & $\begin{array}{c}2014 \\
30-X I I\end{array}$ & $\begin{array}{c}2015 \\
30-\mathrm{VI}\end{array}$ & $\begin{array}{c}2015 \\
20-X I I\end{array}$ & Decrease \\
\hline 1 & 2 & 3 & 4 & 5 & 6 & 7 \\
\hline \multicolumn{7}{|c|}{ SECTION 18} \\
\hline $\begin{array}{l}\text { Semiconductor } \\
\text { thermometers }(\mathrm{T})\end{array}$ & 79 & 79 & 79 & 78 & 79 & 0 \\
\hline $\begin{array}{l}\text { String type thermometers } \\
\text { (TS) }\end{array}$ & 27 & 26 & 25 & 25 & 25 & 1 \\
\hline $\begin{array}{c}\text { Concrete-rock contact } \\
\text { sensors }\end{array}$ & 9 & 6 & 5 & 6 & 6 & 0 \\
\hline $\begin{array}{c}\text { String type crack meters } \\
(\mathrm{C}, \mathrm{CS})\end{array}$ & 44 & 44 & 39 & 42 & 41 & 3 \\
\hline Rebar dynamometers (RD) & 8 & 8 & 8 & 8 & 8 & 0 \\
\hline $\begin{array}{l}\text { Piezometer dynamometers } \\
\text { (PD) }\end{array}$ & 12 & 12 & 11 & 11 & 11 & 1 \\
\hline \multicolumn{6}{|c|}{ Reduction of sensors used for measurement from 20.06 .2014 to 20.12 .2015 , ea } & 5 \\
\hline \multicolumn{7}{|c|}{ SECTION 24 } \\
\hline $\begin{array}{c}\text { Semiconductor type } \\
\text { thermometers }(\mathrm{T})\end{array}$ & 70 & 70 & 70 & 70 & 69 & 1 \\
\hline $\begin{array}{l}\text { String type thermometers } \\
\text { (TS) }\end{array}$ & 42 & 40 & 39 & 39 & 39 & 1 \\
\hline $\begin{array}{c}\text { Thermometers for } \\
\text { determining displacement }\end{array}$ & 50 & 49 & 48 & 48 & 48 & 1 \\
\hline $\begin{array}{c}\text { Concrete-rock contact } \\
\text { sensors }\end{array}$ & 1 & 1 & 1 & 1 & 1 & 0 \\
\hline $\begin{array}{c}\text { String type crack meters } \\
(\mathrm{C}, \mathrm{CS})\end{array}$ & 52 & 49 & 48 & 46 & 48 & 1 \\
\hline Rebar dynamometers (RD) & 6 & 6 & 6 & 6 & 6 & 0 \\
\hline $\begin{array}{l}\text { Piezometer dynamometers } \\
\text { (PD) }\end{array}$ & 13 & 13 & 13 & 13 & 13 & 0 \\
\hline \multicolumn{6}{|l|}{ Reduction of sensors use } & 4 \\
\hline
\end{tabular}

It is seen from the given data that the number of transformers used for diagnostics decreased by 9 units in 2015 compared to 2014. The main reason for the reduction of observations is the failure of generator-frequency meter ЦС $-5 \mathrm{~m}$. This device has morally aged and taken out of production. Frequency meters and period meters produced nowadays don't have the same sensitivity as ЦС $-5 \mathrm{~m}$. That is why it will be possible to recommence observations with a specified group of devices will be possible only after obtaining secondorder devices with the required sensitivity.

The Diagnostic center receives data from Andijan water reservoir in the form of transformer string oscillation periods (microseconds) or thermoresistor resistance values $(\mathrm{Ohm})$. Measurements on about 1250 transformers are taken in one cycle. 26 measurement cycles are carried out in a year. Work on these data starts with their initial processing, which lies in the conversion of transformer electrical signals into physical values [11]. Depending on the characteristics of the transformer output signal, the physical value being 
measured is calculated using the following relationships:

- logarithmic relationship for thermoresistor transformers

$$
\mathrm{y}=\mathrm{A} /(\ln \mathrm{X}-\mathrm{B})-273.15
$$

- parabolic relationship for string transformers

$$
\mathrm{y}=\mathrm{A}^{*}\left(\mathrm{X}^{2}-\mathrm{C}^{2}\right)+\mathrm{B}^{*}(\mathrm{X}-\mathrm{C})
$$

Where

$\mathrm{Y}$ is value being measured

A, B, C are graduated relationship coefficients

$\mathrm{X}$ is transformer output signal.

These calculations are carried out for each of 1250 transformers of static control measurement instrumentation. Table 4 with measurement data, carried out in March of 2015 and the results of their initial processing, is given as an example of information obtained from the water reservoir.

\begin{tabular}{|c|c|c|c|c|c|c|c|}
\hline \multirow{4}{*}{$\begin{array}{l}\text { Device } \\
\text { number }\end{array}$} & \multirow{2}{*}{\multicolumn{3}{|c|}{$\begin{array}{c}\text { Data, transmitted from water } \\
\text { reservoirs for processing }\end{array}$}} & \multirow{4}{*}{$\begin{array}{c}\text { Transfor } \\
\text { mers }\end{array}$} & \multirow{2}{*}{\multicolumn{3}{|c|}{$\begin{array}{c}\text { Results of conversion of electrical } \\
\text { signals into physical values } \\
\text { Measurement dates }\end{array}$}} \\
\hline & & & & & & & \\
\hline & $\begin{array}{c}10 / 01 / 1 \\
5\end{array}$ & $\begin{array}{c}20 / 01 / \\
15\end{array}$ & $\begin{array}{c}10 / 01 / 1 \\
5\end{array}$ & & $10 / 01 / 15$ & $\begin{array}{l}20 / 01 / 1 \\
5\end{array}$ & $10 / 01 / 15$ \\
\hline & \multicolumn{3}{|c|}{$\begin{array}{l}\text { Readings from devices } \\
\text { (microsecond, Ohm) }\end{array}$} & & \multicolumn{3}{|c|}{ Physical values (mm, grad, $\mathrm{kg} / \mathrm{cm}^{2}$ ) } \\
\hline 0 & 6423 & 6424 & 6423 & БТ-7 & -4.194 & -4.2535 & -4.1943 \\
\hline 1 & 5908 & 5909 & 5909 & БТ-8 & -2.198 & -2.2828 & -2.2828 \\
\hline 2 & 6246 & 6243 & 6243 & БТ-9 & -1.834 & -1.6322 & -1.6322 \\
\hline 3 & 6282 & 6282 & 6282 & БТ-10 & 3.0462 & 3.0462 & 3.0462 \\
\hline 4 & 6466 & 6467 & 6468 & БТ-12 & -0.1084 & -0.1661 & -0.2239 \\
\hline 5 & & & & БТ-13 & & & \\
\hline 6 & 6248 & 6249 & 6250 & БТ-14 & -3.2085 & -3.2741 & -3.3396 \\
\hline 7 & 6565 & 6585 & 6564 & БТ -15 & -2.0848 & -2.0848 & -2.0298 \\
\hline 8 & 6380 & 6380 & 6381 & БТ-7 & 4.2659 & 4.2659 & 4.2017 \\
\hline 9 & 7033 & 7033 & 7032 & БТ-16 & 9.9307 & 9.9307 & 9.9531 \\
\hline 10 & 6086 & 6083 & 6084 & TC-31 & 1.3304 & 1.5415 & 1.4711 \\
\hline 11 & 6083 & 6085 & 6082 & БТ-11 & 1.7619 & 1.6241 & 1.8308 \\
\hline 12 & 6240 & 6241 & 6241 & БТ-17 & -0.3769 & -0.4443 & -0.4443 \\
\hline 13 & 6632 & 6626 & 6631 & БТ-18 & -8.9753 & -86583 & -8.9225 \\
\hline 14 & 6337 & 6338 & 6339 & БТ-19 & -3.7545 & -3.8166 & -3.8788 \\
\hline 15 & 6267 & 6281 & 6268 & БТ -20 & -5.7628 & -6.6733 & -5.8280 \\
\hline 16 & 6355 & 6354 & 6355 & БТ-21 & 5.3308 & 5.3925 & 5.3308 \\
\hline 17 & 6415 & 6413 & 6412 & БТ-22 & -9.4542 & -9.3352 & -9.2757 \\
\hline 18 & 6220 & 6219 & 6219 & БТ-24 & -7.5873 & -7.5210 & -7.5210 \\
\hline 19 & 77892 & 7788 & 7787 & БТ -25 & -1.7655 & -1.6312 & -1.5976 \\
\hline 20 & 6543 & 6543 & 6543 & БТ -26 & -1.1296 & -1.1296 & -1.1296 \\
\hline 21 & 7145 & 7149 & 7157 & БТ-27 & 9.5034 & 9.4291 & 9.2809 \\
\hline 22 & 6016 & 6015 & 6015 & TC-38 & 0.5907 & 0.6638 & 0.6638 \\
\hline 23 & 6064 & 6064 & 6063 & БТ-28 & -3.6407 & -3.6407 & -3.5699 \\
\hline 24 & 6232 & 6231 & 6231 & БТ-31 & -5.1491 & -5.0811 & -5.0811 \\
\hline 25 & 6236 & 6235 & 6232 & БТ -32 & -0.6328 & -0.5653 & -0.3625 \\
\hline 26 & 6132 & 6132 & 6133 & БТ-33 & -4.0200 & -4.0200 & -4.0899 \\
\hline
\end{tabular}

Table 4. Measurement data 
Table 4. Measurement data (continuation)

\begin{tabular}{|c|c|c|c|c|c|c|c|}
\hline \multirow{4}{*}{$\begin{array}{l}\text { Device } \\
\text { number }\end{array}$} & \multirow{2}{*}{\multicolumn{3}{|c|}{$\begin{array}{c}\begin{array}{c}\text { Data, transmitted from water } \\
\text { reservoirs for processing }\end{array} \\
\text { Date of measurement }\end{array}$}} & \multirow{4}{*}{$\begin{array}{c}\text { Transfor } \\
\text { mers }\end{array}$} & \multirow{2}{*}{\multicolumn{3}{|c|}{$\begin{array}{c}\text { Results of conversion of electrical } \\
\text { signals into physical values } \\
\text { Measurement dates }\end{array}$}} \\
\hline & & & & & & & \\
\hline & $\begin{array}{c}10 / 01 / 1 \\
5\end{array}$ & $\begin{array}{c}20 / 01 / \\
15\end{array}$ & $\begin{array}{l}10 / 01 / 1 \\
5\end{array}$ & & $10 / 01 / 15$ & $\begin{array}{c}20 / 01 / 1 \\
5\end{array}$ & $10 / 01 / 15$ \\
\hline & \multicolumn{3}{|c|}{$\begin{array}{l}\text { Readings from devices } \\
\text { (microsecond, Ohm) }\end{array}$} & & \multicolumn{3}{|c|}{ Physical values $\left(\mathrm{mm}\right.$, grad, $\left.\mathrm{kg} / \mathrm{cm}^{2}\right)$} \\
\hline 27 & 6794 & 6802 & 6811 & БT-34 & 10.7634 & 10.5881 & 10.3916 \\
\hline 28 & 6619 & 6620 & 6618 & TC-40 & 1.3645 & 1.3107 & 1.4183 \\
\hline 29 & 6513 & 6511 & 6510 & БТ-29 & -1.8129 & -1.7008 & -1.6448 \\
\hline 30 & 6265 & 6265 & 6262 & БТ -35 & -5.3377 & -5.3377 & -5.1431 \\
\hline 31 & 6524 & 6518 & 6514 & БТ-36 & -2.5699 & -2.2154 & -1.9785 \\
\hline 32 & 6145 & 6145 & 6146 & БТ -37 & -8.4079 & -8.4079 & -8.4797 \\
\hline 33 & 7448 & 7461 & 7476 & БТ-38 & 9.7693 & -.5632 & 9.3267 \\
\hline 34 & 6329 & 6330 & 6329 & TC-41 & 0.5039 & 0.4418 & 0.5039 \\
\hline 35 & 6450 & 6448 & 6442 & БТ -30 & 1.8371 & 1.9570 & 2.3174 \\
\hline 36 & 6317 & 6318 & 6317 & БТ-39 & -12.8882 & -12.9505 & -12.8882 \\
\hline 37 & 6787 & 6798 & 6825 & БТ-40 & 11.0533 & 10.8209 & 10.2553 \\
\hline 38 & 6218 & 6214 & 6212 & TC-44 & 0.5597 & 0.8193 & 0.9493 \\
\hline 39 & 6423 & 6422 & 6423 & БТ-41 & -5.5869 & -5.5260 & -5.5869 \\
\hline 40 & 6062 & 6059 & 6056 & БТ-42 & 1.2151 & 1.4303 & 1.6458 \\
\hline 41 & 5961 & 5960 & 5961 & БТ-43 & -6.5667 & -6.4917 & -6.5667 \\
\hline 42 & 6974 & 6990 & 7011 & БТ-44 & 11.5932 & 11.2696 & 10.8480 \\
\hline 43 & 6250 & 6248 & 6247 & TC-45 & 1.7839 & 1.9147 & 1.9802 \\
\hline 44 & 6931 & 6928 & 6926 & БТ-51 & 4.9359 & 5.0786 & 5.1739 \\
\hline 45 & 6267 & 6266 & 6267 & БТ-45 & -10.5833 & -10.4975 & -10.5633 \\
\hline
\end{tabular}

\section{Discussion}

Principles of building the automated system of diagnostical control over the condition of hydraulic structures (ASDC HS) [13] is in the following (Figure 3):

- ASDC system includes in itself an automated system of sensor query (ASQ CMI) and information-diagnostical system (IDS) BING-3, operating in a common computer network (local or corporate) and integrated at the software level.

- ASQ CMI carries out open-end transfer of data from initial sensors to central data collection server. At the data collection server outlet ASQ SMI is integrated with IDS BING-3. Besides, overall ASDC HS is an "open" type AS, which provides stage-by-stage system development, interchangeability of hardware and software means, and compatibility with ASM of other levels.

- ASQ CMI is a distributed system of remote control, which is built according to "industrial network" technology, which provides reliable protection from interferences, reduction in price, and simplification of works in mounting and operation of automated systems.

ASDC HS structurally includes the following elements:

- lower level - control-measurement instrumentation (CMI): sensors, measuring devices;

- medium level - the system of telecommunication, transformation, and transmitting of information in digital code to central data collection block ASQ CMI;

- higher level - program-technical complex, including in itself central automated query block ASQ CMI and information-diagnostic system of control over structure safety (IDS) with corresponding computer hardware and software. 


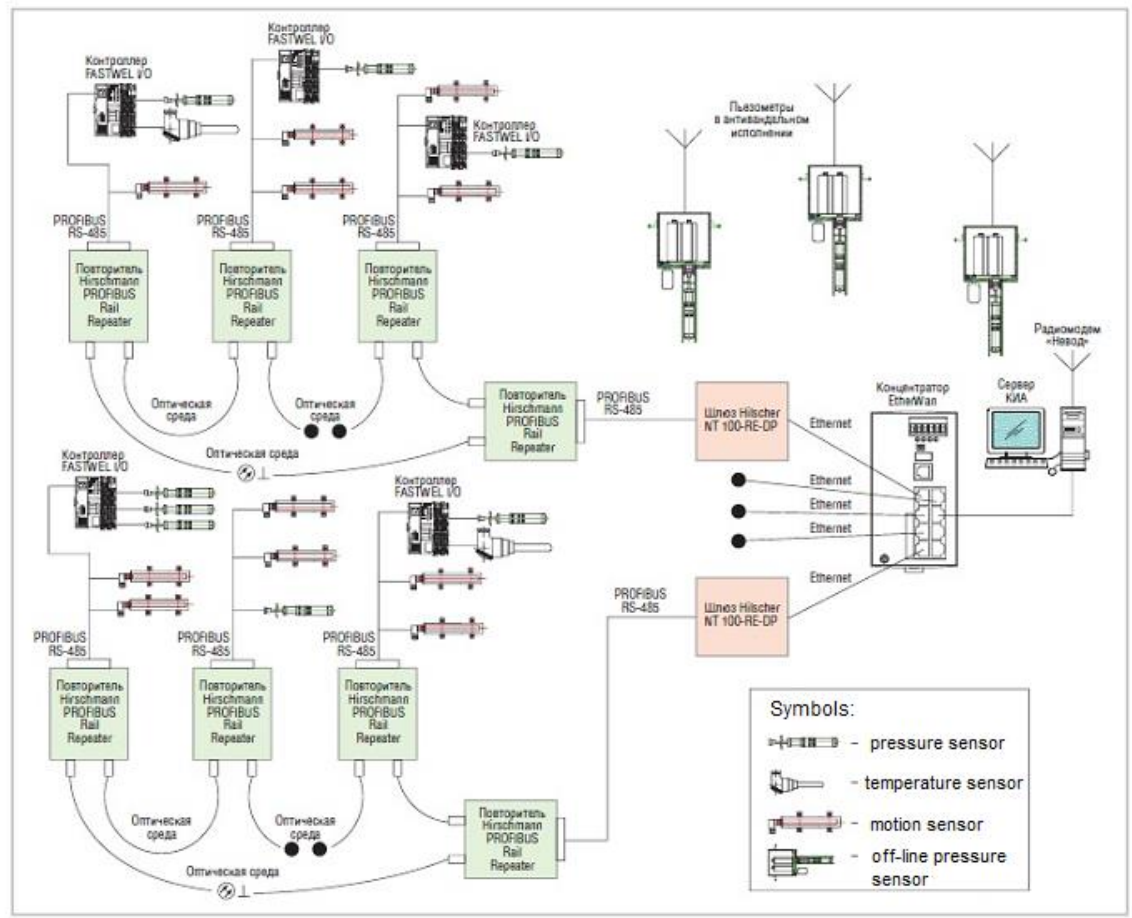

Fig. 3. Simplified structural scheme for data collection system network CMI "BING-3".

At the lower level ASDC directly uses measuring devices with sensors, registering physical processes and impacts on the structure. This automatization system uses water level sensors, sensors of excess pressure in pressure and nonpressure piezometers, discharge meters at drainage wells and measuring weirs, displacement sensors in crack meters, plumbs, string ranges, temperature sensors. The general requirement to sensors is their unified analogue, a digital or radiofrequency outlet of standard type, and interchangeability.

Medium level of ASDC HS includes in itself sensor communication means, transformations of the analogue signal into digital codes, and communication lines for signal transmission from sensors to the central block of automated query system ASQ. Data collection modules, located in the maximum concentration of measuring devices, are used to connect sensors to a communication line with an industrial interface.

Higher level of ASDC HS system is a program-technical complex, including data inputoutput controller, central block based on data collection industrial server, base specialized software for management of automated query of sensors and automated work areas with the complex of programs as part of IDS safety control of HS.

\section{Conclusions}

The main results of the work consist of the following:

1. Collected and analyzed field observation data from Andijan water reservoir concrete dam indicate of their safe operation at its long operation state.

2. Based on the analysis of available data, the main requirements to hydraulic structure operational control systems were determined, i.e., composition and types of field observations, device control means, observation periodicity, and initial data processing seismic monitoring and registering of earthquakes.

3. Permanent control over CMI operational efficiency in the process of monitoring HS 
condition is provided.

4. Use of IDS BING-3 at Andijan hydrosystem allows for automatization of monitoring the condition of all structures at water level, piezometer pressures, discharge measurements, displacement, and temperature.

\section{References}

1. Bakiev M.R., Rahmatov N., Ibraymov A. «Control measurement devices of hydraulic structures» Textbook, p.263, Tashkent, (2019)

2. Bakiev M.R., Rahmatov N., Ibraymov A. Operation of hydraulic structures in canals. Textbook. T, p.280, (2018)

3. Methods for determining safety criteria of hydraulic structures. RAO «GES Russia», M., p.18, (2000)

4. Regulations on hydraulic structure sites, RD 254. 073-98. Minenergo RUz, Tashkent.

5. M. Malahanov. «Technical diagnostics of earthfill dams» M.(1990)

6. Basic rules on operation of water reservoirs with capacity of $10 \mathrm{mln} . \mathrm{m}^{3}$ and over. RD 33-3. 02.08-87. Official publ. M., (1987)

7. Kuzmin N.G., Rasskazchikov V.A., Ulyashinski V.A. Strength and deformation properties of concrete and strength properties of rock base of Krasnoyarssk GPS dam after 40 years of operation period. Info VNIIG of B.E.Vedeneev., T. 276. pp. 46-55, (2014)

8. Kuzmin N.G. Particularities of condition concrete dam of Krasnoyarsk HPS at longterm operation stage. Info VNIIG of B.E.Vedeneev. T. 276. pp. 24-32. (2015)

9. Lyutsko E.A. Monitoring the condition of Chirkey HPS dam. Info VNIIG of B.E.Vedeneev. T.237. pp.40-44. (2001)

10. Mayorova M.A., Sokolovski I.K. Methods for choosing the frequency of field observations. Info VNIIG of B.E.Vedeneev. T. 241. pp.137-143, (2002)

11. Mayorova M.A. Methods of initial Способы pre-processing of field observation data. Info VNIIG of B.E.Vedeneev. T. 237. pp.40-44, (2000)

12. Kuzmin N.G. C.t.s. dissertation «Improving the system of control of Krasnoyarsk HPS concrete dam condition (on the example of Krasnoyarsk HPS).

13. Sherbina. Presentation in Almati city, «Installation in Orto-Tokoy hydrosystem of computer-diagnostic system to control safe condition of hydrotechnical structures (BING-3).» (2010)

14. Melnikov E., Morozov V., Krasnoshekov I. «Developing the system of control over condition of hydrotechnical structures of shipping lock »

15. Nosova O.N. Basic rules of processing observation results of piezometers for field observations of filtration». Info VNIIG. T.81.(1966)

16. KMK 2.06.01-96 Hydraulic structures. Basic design rules.

17. Rosanov N.P. and others «Hydraulic structures» (1985)

18. Bochkaryov Ya.V., Ovcharov E.E. Principles of automatics and automatization of production processes in hydromelioration. -M.: Kolos, - p.332, (1981)

19. Goncharov L.A., Komarov V.A., Lentyaev L.D. and others. - Complex field hydraulic observations of spillway structures. Research works Gidroproekt. - M. - Ed. 91. pp.9-20, (1983)

20. Methodical recommendations to developing of arrangement design of control measurement devices in concrete structures. pp.41-70 Minenergo, - L.: VNIIG, p.102, (1971)

21. Bazarov D., Vatin N., Obidov B., and Vokhidov O. Hydrodynamic effects of the flow on the slab of the stand in the presence of cavitation. IOP Conf. Ser. Mater. Sci. Eng. 
1030, 012110 (2021).

22. Bazarov D., Markova I., Norkulov B. and Vokhidov O. Hydraulic aspects of the layout of head structures during water intake from lowland rivers. IOP Conf. Ser. Mater. Sci. Eng. 1015, 012041 (2021).

23. Shokirov B., Norkulov B., Nishanbaev Kh., Khurazbaev M., Nazarov B. Computer simulation of channel processes. E3S Web of Conferences, 97, 05012, (2019)

24. Bazarov D., Markova I., Sultanov S. and Kattakulov F. Dynamics of the hydraulic and alluvial regime of the lower reaches of the Amudarya after the commissioning of the Takhiatash and Tuyamuyun hydrosystems. IOP Conf. Ser. Mater. Sci. Eng. 1030, 012110 (2021).

25. Bazarov D. and Vokhidov O. Extinguishing Excess Flow Energy in Spillway Structures. In book: Proceedings of EECE 2020, LNCE 150, pp. 535-545, (2021) DOI: $10.1007 / 978-3-030-72404-7 \_52$

26. Krutov A., Choriev R., Norkulov B., Mavlyanova D. and Shomurodov A. Mathematical modelling of bottom deformations in the kinematic wave approximation. IOP Conf. Ser. Mater. Sci. Eng. 1030, 012147 (2021).

27. Bazarov D., Markova I., Norkulov B., Isabaev K., Sapaeva M. Operational efficiency of water damless intake. IOP Conf. Ser. Mater. Sci. Eng. 869(7), 072051, (2020)

28. Krutov A., Norkulov B., Uljaev F., and Jamalov F. Results of a numerical study of currents in the vicinity of a damless water intake. IOP Conf. Ser. Mater. Sci. Eng. 1030, 012121 (2021).

29. Obidov B., Vokhidov O., Tadjieva D., Kurbanova, U., Isakov A. Hydrodynamic effects on the flow elements of the downstream devices in the presence of cavitation. IOP Conf. Ser. Mater. Sci. Eng. 1030, 012114 (2021).

30. Krutov A., Norkulov B., Mavlyanova D. Simulation of spreading of non-conservative passive substances in water bodies. IOP Conf. Ser. Mater. Sci. Eng. 883(1), 012028 (2020)

31. Bazarov D., Norkulov B., Vokhidov O., Uljaev F., Ishankulov, Z. Two-dimensional flow movement in the area of protective regulatory structures. IOP Conf. Ser. Mater. Sci. Eng. 890, 012162 (2020)

32. Krutov A., Norkulov B., Nurmatov P., Mirzaev M. Applicability of zero-dimensional equations to forecast nonconservative components concentration in water bodies. IOP Conf. Ser. Mater. Sci. Eng. 883(1), 012028 (2020)

33. Uralov B., Rakhmatov N., Khidirov S., Uljaev F., Raimova I. Hydraulic modes of damless water intake. IOP Conf. Ser. Mater. Sci. Eng. 1030(1), 012123 (2021)

34. Krutov A., Norkulov B., Artikbekova F., Nurmatov P. Optimal location of an intake at a reservoir prone to salt diffusion. IOP Conf. Ser. Mater. Sci. Eng. 869(7), 072020, (2020)

35. Bazarov D., Markova I., Raimova I., Sultanov Sh. Water flow motion in the vehicle of main channels. IOP Conf. Ser. Mater. Sci. Eng. 883, 012025 (2020).

36. Matyakubov B., Begmatov I., Raimova I. and Teplova G. Factors for the efficient use of water distribution facilities. IOP Conf. Ser. Mater. Sci. Eng. 883, 012025 (2020). 